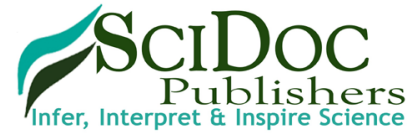

International Journal of Finance, Economics and Trade (IJFET) ISSN 2643-038X

\title{
Consumer Perception and Marketing Relationship in Food Quality, Safety and Applications
}

Research Article

Kara $G^{*}$

Institute of Department of Business, Karabuk University, Karabuk, Turkey.

\section{Abstract}

Rapid population growth today has led to a high demand in the fields of food production and marketing. The producers have tended towards new ways in order to achieve faster and higher yields in production techniques to meet increasing demand. Products containing food additives have advantages over organic products in terms of long-term preservation without compromising taste. Despite this, food additives' adverse effects on human health and the environment is inevitable unless used at suitable amounts specific to the product in question. This gradually increases the interests of the consumers regarding the organic products obtained by the traditional production methods and causes a dilemma for producers determining the marketing policies in relation to the organic production versus the production using food additives.

Keywords: Natural Production; Relationship Marketing; Business Marketing; Marketing Policies.

\section{Introduction}

Marketing relationship can be defined as the basic relationship between supplier and customer [1-3]. In this relationship, policies are being made in order to fulfill the goals of both parties. Businesses focus on marketing policies to ensure consumer satisfaction with a reasonable profit and to make it sustainable [4-6].

In line with the rising population today, the idea of meeting the rising demand for food has led to high-yield and long shelf life policies in food production and marketing. Especially developed countries have begun to produce additives that provide high-yield and long shelf life in food production by utilizing the advances in technology in order to get into new domestic and foreign emerging markets. However, debates still continue on the issue of food safety and food reliability in relation to the food additives used in these products.

This perception increases the demand of consumers towards the organic products [7] and causes an organic-production vs. production with additives dilemma for producers. In recent years, the interest in production and purchasing organic food continues to grow among consumers and producers [8]. Especially in European countries, organic market share grew rapidly [9]. Although this rapid development varies from country to country, organic food production and marketing is not at the desired level in terms of continuity in food market share and amount of production. In spite of this, the intensive interest of consumers has contributed to the development and sustainability of organic food, which has shown significant improvements in agricultural policies $[10,11]$. In the majority of the studies conducted, it has been found that the organic food products have favorably welcomed by consumers, showing an interest in these products $[12,13]$. However, lack of information on organic food production has led to the exploitation of this area by irresponsible producers [14].

Few studies have been conducted that anticipate consumer and producer behavior as well as the development of the food market [15]. Therefore, this study is important since it was conducted to explain the effect of techniques and marketing of organic food and products with food additive on the consumer behavior and perception.

The study is organized in three sections. In the first part, short and descriptive information about the literature was provided. In the next section, common misconceptions about food production techniques and marketing policies were discussed. In the last section, the results of the analysis were interpreted.

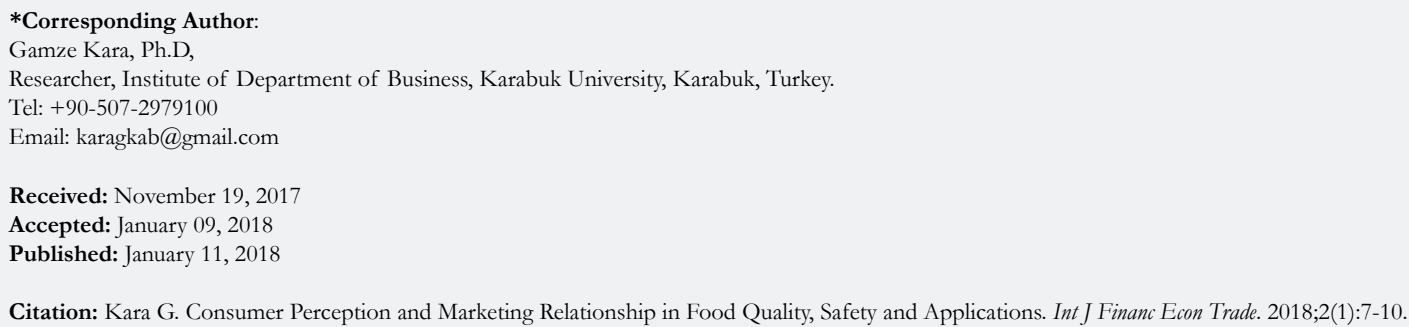

Copyright: Kara $\mathbf{G}^{\circ}$ 2018. This is an open-access article distributed under the terms of the Creative Commons Attribution License, which permits unrestricted use, distribution and reproduction in any medium, provided the original author and source are credited. 


\section{Loss and Waste}

There are losses in products that are not stored under appropriate conditions. As the losses increase, the cost increases and this is reflected as a price increase for the consumers. One of the policies to reduce losses is to store products that are abundant during the season for longer periods without wasting them. This is because it is inevitable that there will be losses in products which are not consumed in time and are not stored properly. This result encourages the producer to opt for long-term healthy preservation by using additives suitable for the food products. On the other hand, the use of inappropriate (not used in appropriate products) and illegal additives causes problems in human health and environmental pollution.

\section{What is Organic Production?}

In general, organic production can be defined as the production system carried out using natural methods to control biological pests and using animal manure, legumes and organic plant residues as much as possible for fertilization purposes without the use of synthetic fertilizers, pesticides, growth regulators or animal feed additives [16].

The main purpose of organic production is to produce all kinds of food and nutrients that people use without or minimal harm to human health in a sustainable manner [17]. The development of organic production has been encouraged both by international organizations and local laws in order to protect human health, to use natural resources rationally and to protect agro-environment relations [18].

Organic production not only contributes to human health but also to the protection of the environment. It prevents the reduction of existing agricultural areas, desertification and maintains their usability. The marketing in this regard is supported by raising public awareness about the organic products, operating under an affiliated marketing organization and certifications issued by the official organizations indicating that certain conditions are met.

There is a common consensus among consumers about the need to preserve the quality of organic products [9]. Therefore, consumers want to buy fresh organic products. However, the exorbitant price policy practices of the organic product markets prevent accessibility [19]. This problem can be solved by providing a direct contact between organic food producers and consumers (through direct sales) and bringing prices down to normal levels. For example, organic food sales in Sweden, Denmark, Finland, the UK and Austria are handled with direct marketing or specialty shops for marketing (20 EU 2003). In addition, the lower production cost of the same products with food additives is effective in lowering the prices of organic producers.

Consumers show great interest in organic vegetables, fruits, milk and eggs [21]. Consumers want increased diversity of limited organic products. Organic food production is usually carried out by small businesses in small areas. These products obtained in small areas make a small profit. In addition, limited production causes problems such as marketing and transportation. The other problem is that the income status and the educational status of organic food producers are low. Especially the low educational level of the producers is an important problem. For example, the selection and amount of use of organic pesticides to be used against pests and diseases that may occur in products is generally handled in an unconscious manner as far as learned from ancestors. It is important to address training deficiencies of producers when determining agricultural policies.

\section{Food Additives}

Food additive is defined as substances which are not consumed as food alone or used as raw or auxiliary food substances, but can be found as a residue or derivatives in the finished product during the production process used in accordance with the selected technology [22]. Food additives are used to protect, correct or prevent unwanted changes in the taste, odor, appearance, structure and other properties of food during the production, classification, processing, preparation, packaging, transport and storage of foodstuffs [23]. They are used to protect the food for a long time without spoilage, to color and sweeten the food, to increase the taste or nutritional value of the food. In the use of food additives, it is important to ensure that they are not harmful to human health, do not reduce the nutritional value of the food used, and are used at amounts allowed by law. These additives can be artificial (aspartame;sweetener). or natural (vegetable carbon;colorant in black powder form), and nature-identical (vanilla) substances.

When functionally classifying food additives [23], they can be classified as stabilizer and sequestrants that preserve and improve the nutrient value (especially the ones that lost during cooking), colorants, flavorants and sweeteners, anti-caking agents and enzymes, and antioxidants to protect against oxidation (for longer shelf life).

The human body has several mechanisms to counteract oxidative stress by producing antioxidants, which are either naturally produced (endogenous antioxidants) in situ, or externally supplied (exogenous antioxidants) through foods and/or supplements [25]. The roles of antioxidants are to neutralize the excess of free radicals, to protect the cells against their toxic effects and to contribute to disease prevention $[25,26]$. However, only within the last two decades, has there been an explosive discovery of their roles in the development of diseases, and also of the health protective effects of antioxidants $[25,26]$.

Food additives are very functional according to their purpose of use;

- The $\mathrm{pH}$ value can be adjusted as desired in order to ensure a long shelf life for foods. With this value, the sweetness and mordancy of the food can also be adjusted if desired. In particular, increasing $\mathrm{pH}$ values increase the sensitivity of food to heat so that many pathogenic and food-degrading microorganisms degrade foods. In order to prevent this, low $\mathrm{pH}$ values can be obtained with suitable additives in the produced foods.

- Extend shelf life with their antioxidant properties. They are used to prevent the undesirable smell, aroma, taste changes, and color loss due to oxidation that may occur over time in food products.

- The flavor can be improved by adding to the foods to make the 
flavor of the product more attractive or to protect the food.

- They are also added to accelerate the natural fermentation process, to shorten the cooking process and to improve the quality of the product.

If the food contaminants (chemical contaminants in the food) in the food are kept below the limits determined using the risk analysis methods, then their adverse effects are considered within the "Acceptable Risk" limits. Safety tests related to the use of food additives are carried out on laboratory animals in a long-term and detailed manner [27]. These tests first determine the amount of dietary ADI (Acceptable Daily Intake) of the additives using toxicological tests performed on laboratory animals. Lethal doses of additives are then given to the laboratory animals. In the next steps, the dose given to the laboratory animals is reduced and the biological, chemical and allergic effects on the laboratory animal are examined. This continues until the dose in which the additive used has no side-effects (dose-response relationship). This dose is defined as the "ineffective dose" or NOAEL (no-observed-adverse-effect-level). The ineffective dose is determined in $\mathrm{mg}$ per kilogram of the laboratory animals used. The major contradiction here is that additive food are produced by determining the amount of food additives to be used according to the amount of doses that have no side-effects on laboratory animals. It is not possible to know in advance how this will affect people who consume this food with additives.

\section{Results and Discussion}

The use of food additives as a technological obligation to meet the increasing demand for food has become inevitable and open to the abuse of unconscious producers. Malicious producers can use food additives to increase profit margins in food products and to outshine the poor quality that consumers may notice. The opinion that all the additives are harmful to human health is not correct. The most important factor that determines the adverse effects of food additives on human health and environment is the amount of additive used. Scientific studies are being conducted to determine these quantities and results are published [28].

Food additives are known to prevent oxidation products or harmful peroxides that may form over time in food when used in quantities specified for the related product. For example, when a natural orange juice is put in an empty pet bottle it will explode in a week due to microorganisms that cause decomposition. It is possible to keep these products healthy for a long time by killing the microorganisms that cause decomposition in these products (by keeping at $95-99^{\circ} \mathrm{C}$ for $30-60$ seconds and immediately cooling juices down to $20^{\circ} \mathrm{C}$ ) and packing appropriately to prevent contamination with microorganisms after adding suitable additives. Heat treated fermented sausage, salami, sausage products are examples of this treatment. However, it should be noted that the treated fruit juice and the fruit itself are different things.

Food additives are standardized by an international numbering system. These numbers are important for clarification of each additive (colorants, preservatives, antioxidants, etc.) in the food. For example, the letter " $\mathrm{E}$ " is the first letter of the word Europe and indicates that there are approved additives in packages in the European Union countries. It indicates that all safety work has been carried out on the product and has been approved by the European Food Safety Authority (EFSA). There are many unscientific news stating that E-coded food products make cancer. The health risks of food additives are determined by toxicological tests and are published by international organizations. In line with these results, those do not pose a health risk are used.

Enterprises determine their marketing policies under the dilemma of the organic production versus the production with additives. Enterprises are interested in additives due to the superior properties (such as long shelf life, higher yield, etc.) of the products with food additives. Consumers also want their products to be consumed for a long time without losing their taste and nutritional value. However, no feature is more important than human health.

Consumers are faced with media reports stating that food additives have a carcinogenic effect. Scientific studies show that less than $1 \%$ of all cancer causes may be due to food additives [28]. It should be noted that no food additive is toxic. What is toxic is the dose used. It is also not true that all food additives are artificial. Important part of food additives are natural and semi-natural additives. In addition, the perception that everything natural is healthy and everything artificial is unhealthy is a wrong perception. Since the products with additives change the taste and flavor of the food, they become more addictive since they are more appreciated, and the organic form of the product is not preferred as a result. The perception that there is no adequate scientific research for food additives is also wrong. Oxidations in organic products in time can lead to serious problems in terms of human health. Additives used within the legal limits eliminate the health risk thanks to their antioxidant properties.

\section{Conclusions}

The positive effects of food additives on production and marketing have made the use of these products inevitable. However, conscious consumers are now inclined to consume organic products due to severe problems of additives on human health and the environment. However, there is a continuing controversy going on in the media about the negativities of them. Especially feeding the younger children with the products produced with additives for a long period of time has created an awareness in society and a demand for the products grown with organic production has been emerged. The production and marketing industries continue to work in order to meet this demand. The low yield of organic products, except their seasons, the lack of a long shelf life, and the storage and quick delivery needs affect the sale price of the organic products. And, particularly the medium- and low-income families tend to consume cheaper processed products because of this fact. In the production and marketing sector, there is a contradiction between the organic production and the production with additives. Although there are false facts about the production with additives, they have become a technological necessity in industrial production. The problem here is the use of additives in specified quantities and in specified products within the legal limits. Control is important and food safety must be provided at every stage. Food safety tests, determined by international standards, are required for the additives used. However, the risk will never be zero since each person may have experience different adverse effects due to the different anatomy and biological clock (the effects on children and adults may differ). Consumers need 
to know how these products have been produced. And, producers should plan their sales and marketing strategies accordingly.

\section{References}

[1]. Gummerus J, von Koskull C, Kowalkowski C. Guest editorial: relationship marketing-past, present and future. Journal of Services Marketing. 2017 Feb 13;31(1):1-5.

[2]. Chang YS, Fang SR. Enhancing export performance for business markets: effects of interorganizational relationships on export market orientation (EMO). Journal of Business-to-Business Marketing. 2015 Jul 3;22(3):21128.

[3]. Storbacka K, Nenonen S. Competitive arena mapping: Market innovation using morphological analysis in business markets. Journal of business-tobusiness marketing. 2012 Jul 1;19(3):183-215.

[4]. Barnes JG, Howlett DM. Predictors of equity in relationships between financial services providers and retail customers. International Journal of Bank Marketing. 1998 Feb 1;16(1):15-23.

[5]. Reichheld FF. Learning from customer defections.

[6]. Szmigin I, Bourne H. Consumer equity in relationship marketing. Journal of Consumer Marketing. 1998 Dec 1;15(6):544-57.

[7]. Alvensleben RV. Ecological aspects of food demand: the case of organic food in Germany. Institute for Agricultural Economics, University of Kiel. 1998;4:68-79.

[8]. Lampkin N. Organic farming. Farming press books; 1990.

[9]. Michelsen J, Hamm U, Wynen E, Roth E. The European market for organic products: Growth and development. Universität Hohenheim-Stuttgart Hohenheim; 1999.

[10]. Padel S, Foster C. Exploring the gap between attitudes and behaviour: Understanding why consumers buy or do not buy organic food. British food journal. 2005 Aug 1;107(8):606-25.

[11]. Lotter DW. Organic agriculture. Journal of sustainable agriculture. 2003 Apr 1;21(4):59-128.

[12]. Wandel M, Bugge A. Environmental concern in consumer evaluation of food quality. Food quality and preference. 1997 Jan 31;8(1):19-26.

[13]. Magnusson MK, Arvola A, Koivisto Hursti UK, Åberg L, Sjödén PO. Attitudes towards organic foods among Swedish consumers. British food journal. 2001 Apr 1;103(3):209-27.

[14]. Hamm U, Gronefeld F. The European market for organic food: revised and updated analysis. The European market for organic food: revised and up- dated analysis. 2004.

[15]. Critcher C, Gladstone B. Utilizing the Delphi technique in policy discussion: a case study of a privatized utility in Britain. Public administration. 1998 Jan 1;76(3):431-49.

[16]. Browne AW, Harris PJ, Hofny-Collins AH, Pasiecznik N, Wallace RR. Organic production and ethical trade: definition, practice and links. Food policy. 2000 Feb 29;25(1):69-89.

[17]. Padel S, Midmore P. The development of the European market for organic products: insights from a Delphi study. British Food Journal. 2005 Aug 1;107(8):626-46.

[18]. Kortbech-Olesen R. Export opportunities of organic food from developing countries. International Trade Center. Suiza. 2000 May.

[19]. Fotopoulos C, Krystallis A. Organic product avoidance: reasons for rejection and potential buyers' identification in a countrywide survey. British Food Journal. 2002 Apr 1;104(3/4/5):233-60.

[20]. European Commission . Organic farming in the European Union: facts and figures. available 2003;1-30.

[21]. Chaudhry Q, Scotter M, Blackburn J, Ross B, Boxall A, Castle L, Aitken R, Watkins R. Applications and implications of nanotechnologies for the food sector. Food Addit Contam Part A Chem Anal Control Expo Risk Assess. 2008 Mar;25(3):241-58. PubMed PMID: 18311618.

[22]. Dimitri C,Oberholtzer L.Marketing U.S. Organic Foods: Recent Trends from Farms to Consumers,USDA, Economic Research Service.September 2009; Economic Information Bulletin, 58.

[23]. Martinez-Tome M, Jimenez AM, Ruggieri S, Frega N, Strabbioli R, Murcia MA. Antioxidant properties of Mediterranean spices compared with common food additives. J Food Prot. 2001 Sep;64(9):1412-9. PubMed PMID: 11563520.

[24]. Furia TE. CRC handbook of food additives. CRC press; 1973 Jan 2.

[25]. Pham-Huy LA, He H, Pham-Huy C. Free radicals, antioxidants in disease and health. Int J Biomed Sci. 2008 Jun; 4(2): 89-96. PubMed Central PMCID: PMC3614697.

[26]. Valko M, Leibfritz D, Moncol J, Cronin MT, Mazur M, Telser J. Free radicals and antioxidants in normal physiological functions and human disease. The international journal of biochemistry \& cell biology. 2007 Dec 31;39(1):44-84.

[27]. Gilbert J, Vargas EA. Advances in sampling and analysis for aflatoxins in food and animal feed. Journal of Toxicology: Toxin Reviews. 2003 Jan 1;22(2-3):381-422.

[28]. Zweig G, editor. Principles, Methods, and General Applications: Analytical Methods for Pesticides, Plant Growth Regulators, and Food Additives. Elsevier; 2013 Sep 11. 